\title{
Evaluation of the Prevalence of Subclinical Mastitis in Dairy Cattle in the Soummam Valley (Bejaia, Algeria)
}

\author{
Asma Ait KAKI ${ }^{1}$, Salem DJEBALA ${ }^{2}$, Muhammad Bilal LATIF ${ }^{3}$, Nassim MOULA² ${ }^{2 *}$ \\ ${ }^{1}$ Department of Biology, Faculty of Sciences, M'Hamed Bougara University of Boumerdes, 3500 \\ Boumerdes, Algeria \\ ${ }^{2}$ Department of Animal Production, Fundamental and Applied Research for Animal and Health, Faculty of \\ Veterinary Medicine, Liege University, B-4000 Liege, Belgium \\ ${ }^{3}$ Department of Inflammation and Immunity, Lerner Research Institute, Cleveland Clinic, Cleveland, $\mathrm{OH}$ \\ 44195, USA \\ *corresponding author: nassim.moula@uliege.be
}

Bulletin UASVM Veterinary Medicine 76(2)/2019

Print ISSN 1843-5270; Electronic ISSN 1843-5378

doi:10.15835/buasvmcn-vm:2019.0006

\begin{abstract}
:
The present study was carried out to investigate the prevalence of subclinical mastitis (SCM) in milking cows and the effect of farming system on the prevalence of SCM", as well as the identification of bacterial strains causing the mammary gland infection. A total of 100 dairy cows were randomly selected from 32 farms of Bejaia district (Algeria), precisely the Soummam region: from Tazmalt to El Kseur. The SCM was screened by California Mastitis Test (CMT). Milk samples were collected aseptically from (CMT) positive cows and dispatched to laboratory for further microbiological tests. Results showed that the prevalence of SCM was $26 \%$. Moreover, no significant differences in SCM prevalence were observed between intensive and semi intensive systems ( $\mathrm{P}>0.05)$. The Staphylococcus aureus was found to be the most frequent bacterium species associated with SCM in the cows studied.
\end{abstract}

Keywords: CMT; farming, milking cows; mammary infection.

\section{Introduction}

Algerian people rank among largest milk consumers in the world with an average consumption of 110 liters of milk per capita per year. On the other hand, according to a recent study carried out by the researchers from RCAED (Research Center of Applied Economics for Development) showed that Algeria produces milk that suffices the needs of only $30 \%$ of its inhabitants. In fact, the cow milk production is currently about 2.5 billion liters of which less than a third is collected by the dairy industry while the rest is consumed locally or given to the cattle. As a result, $70 \%$ of the milk requirement is fulfilled by importing it from abroad in form of milk powder. Algeria imports about 18000 tons of whole milk and skimmed milk powder in a year that makes Algeria the $3^{\text {rd }}$ and the $1^{\text {st }}$ largest milk importer in the world, respectively. The import bill has reached up to $\$ 1.5$ billion in 2017 (Semmar, 2018).

Cow milk production in Algeria is concentrated mainly in three zones; Zone I ( $60 \%$ of dairy cows) is a coastal and a sublittoral with a humid and subhumid climate, Zone II ( $26 \%$ of dairy cows) is agropastoral and pastoral regions with a semi-arid and arid climate, Zone III (14\%) is located in the Saharan region with a desert climate (Kali et al., 
2011). The Bejaia district in which this study is done belongs to Zone I.

Dairy cow farming in Algeria is currently facing many problems and constraints created by diverse factors. The main origin of these problem creating factors is the mismanagement of natural, technical and human resources. This includes the exploitation of agricultural land, water potential, forage potential, cattle breeds, numbers of cattle, farm management, feeding control, reproductive behavior and the health status of cows (Abdeldjalil, 2005).

It is to note that mastitis is the most common health problem with the highesteconomicimpactin dairy farming (Poutrel, 1985, Seegers et al., 2003). Mastitis is a mammary gland infection, usually caused by bacteria which induce the inflammation of one or more quarters of the udder. However, socalled "aseptic" mastitis exists and it may be due to the physiological disorders or local trauma, but it is much rare. Mammary gland infection may or may not be associated with clinical signs and are named as clinical mastitis and subclinical mastitis (SCM), respectively (Poutrel, 1985; Seegers et al., 2003).

The diagnosis of acute or hyperacute form of clinical mastitis is relatively simple, as the general and local signs are obvious (fever, abatement, swollen area) with a change in the appearance of milk. However, the number of cows with such symptoms remains low in the herd. Beside this, mastitis can be fatal like in Nocardia gangrenous mastitis or colibacillary mastitis (Kayesh et al., 2014; Radostis et al., 2007). In SCM, there is no evidence of macroscopically obvious inflammation but examination of the milk reveals the existence of the infection; an increase in the number of somatic cells and the presence of certain microorganisms in the milk, and alteration of its chemical properties. In fact, different studies have shown that SCM is mainly caused by contagious pathogens including Coagulase Negative Staphylococci (CNS), Staphylococcus aureus, Streptococcus agalactiae, and Mycoplasma bovis, and by environmental pathogens such as Streptococci (e.g., Streptococcus dysagalactiae and Streptococcus uberis), and the Enterobacteriaceae (Shahid et al., 2011).

The mastitis has been identified as the most economical loss causing disease in dairy industry. In fact, on an average herd size that was 637 dairy cows in the study of Pfützner and
Ózsvári (2017), a total decrease of gross milk was calculated to be almost $€ 241,000$ per year. Beside this, the negative commercial impact of mastitis is detrimental for the cheese production industry. During mastitis, physicochemical and biological changes in milk reduce its commercial quality and consequently affect its processing. This leads to a decrease in cheese yield, and a change in texture, taste and smell. In addition to that, the blood proteins (immunoglobulins, serum albumin, plasmin, etc.) passed in the milk during mastitis and reduce the stability of milk during heat treatments (Serieys, 1985). Furthermore, the proteolytic effect of the blood plasmin reduces the UHT milk stability during its storage. Finally, the presence of antibiotics in the cow milk after mastitis treatments may cause a partial or total inhibition of bacterial ferments that can lead to a bad dripping during cheese production, and the invasion of colibacillary flora and molds. For example, a standard dose of penicillin is sufficient to stop the lactic fermentation of 1000 liters of milk (Guerin-Faublee et al. 2003).

The economic losses caused by mastitis are through disease control actions which include treatments and prevention and through other diverse losses, such as reduction in production, non-marketed milk, sales price penalties, mortality and anticipated reforms, bad milk quality. However, subclinical mastitis causes losses more than three times than the clinical mastitis (Kayesh et al., 2014; Singh and Singh, 1994) because it is silent, more serious and causes much greater loss to the dairy industry (Abrahmsen et al. 2014; Pfützner and Ózsvári, 2017).

The present study was conducted to determine the prevalence of subclinical mastitis and to isolate, and identify the bacterial agents associated with SCM in lactating cows in Bejaia district (Algeria), and to assess the relative prevelance of SCM in the two production systems (semi-intensive and intensive).

\section{Materials and methods Study area and sampling method}

This study was carried out from March till May 2018, in the region from Tazmalt to El Kseur in the district of Bejaia (about $250 \mathrm{~km}$ from Algiers). Thirty-two farms were studied during this study, including 18 intensive and 14 semi-intensive farms. Two cows per semi-intensive farm and 


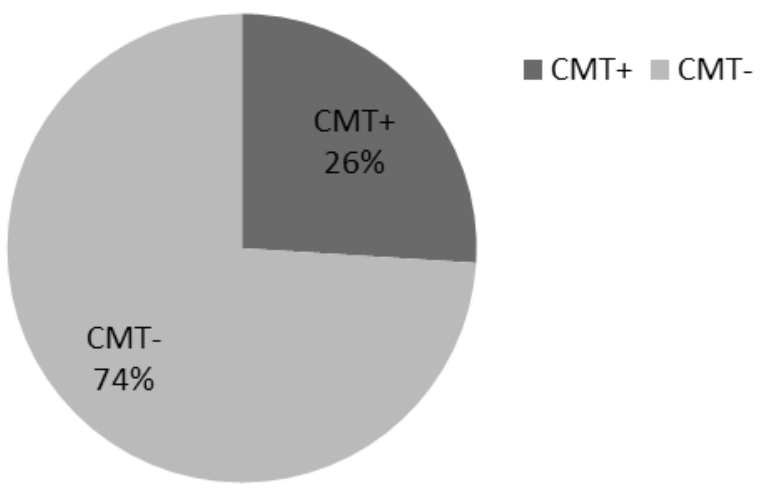

Figure 1. Frequency of subclinical mastitis in dairy cows reared in intensive and semi-intensive farms, 32 farms in total, situated at the district of Bejaia (from Lakseur to Tazmalt in Bejaia city), in Algeria.

4 cows per intensive farm were selected for the study, which correspond to a total of 100 lactating cows. First milk jets were removed then $40 \mathrm{ml}$ milk sample from each quarter was filled in a sterile tube. A total of $160 \mathrm{ml}$ milk sample from each cow was further used for CMT test and bacteriological analysis. Cows were randomly selected excluding the cows presenting symptoms of the clinical mastitis.

\section{Aseptic milk sample collection}

Milk samples were collected from 100 milking cows. Just before collecting the milk, udder and milker's hand were washed with clean water and teats were swabbed with cotton soaked in $70 \%$ alcohol and $8^{\circ}$ Chlorometric bleach solution. Then, milk samples were collected aseptically from the teats at the time of milking into sterile tubes after discarding the first 3 milking streams. After collection, the milk samples were labeled and immediately transported in an ice-cooled box and later transferred into a fridge at $4{ }^{\circ} \mathrm{C}$. Milk samples were processed within $24 \mathrm{~h}$ after the collection as described by Biru (1989).

Detection of subclinical mastitis and bacterial analyses

From milk samples, the SCM was detected by the California Mastitis Test (CMT: Teepol ${ }^{\circledR}$ vial, opaque blister packs). The CMT test was conducted using score from 1 to 5 according to the Scandinavian scoring system, where; 1 is negative result (no gel formation), 2 is traceable (possible infection), 3 or above indicates a positive result, 4 and 5 has the most gel formation. All milk samples from cows with CMT $\geq 3$ were subjected to further bacterial examination. The Techniques on culture methods, colonies morphology, differentiation of bacteria between gram + and gram - and biochemical tests conducted to identify isolated bacteria according to the International dairy Federation, 1981 (Waage et al., 1994)

\section{Statistical analyses}

G*Power 3.1.9.2 was used to estimate the minimum sample for this study. Based on the results obtained in Algeria, on the average frequency of SCM reported by Bouzid et al. (2011) and Saidi et al. (2016), which was about $30 \%$ of positive results; assuming a significance level of $\mathrm{P}<0.05$, and a statistical power of 0.8 , the required sample for our study was estimated as 93 lactating cows to expect a statistically significant difference. To remedy any unexpected surprise we decided to analyze 100 lactating cows. After performing a descriptive analysis of the data, the $\mathrm{Chi}^{2}$ test was used to compare the frequency of SCM and the frequencies of isolated bacterial strains. The significance threshold was set at $\mathrm{P}<0.05$. All statistical analyses were performed by SAS software.

\section{Results and discussions}

The percentage of negative subclinical mastitis was significantly $(\mathrm{P}<0.05)$ higher $(64 \%)$ compared to the positive SCM (26\%) detected by the CMT test (Figure 1). Cows undergoing SCM were counted among the total number of animals analyzed.

No significant differences $(P>0.05)$ were recorded in the SCM frequencies between the two livestock systems, i.e., $21.2 \%$ for the semi-intensive and $27.8 \%$ for the intensive farms (Figure 2). 


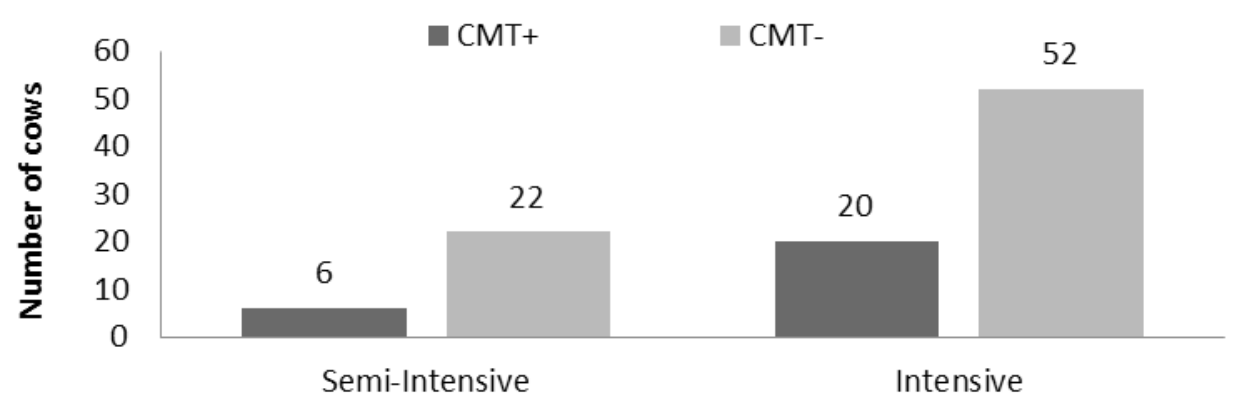

Breeding system

Fgure 2. Comparison of subclinical mastitis frequencies of dairy cows between intensive and semiintensive farms in the district of Bejaia (Algeria)

Table 1. The prevalence of bacterial species in milk samples of $26 \mathrm{CMT}^{+}$dairy cows

\begin{tabular}{ccc}
\hline Bacterial strains & Number of CMT+ cows & Percentage (\%) \\
\hline Staphylococcus (S) aureus & 11 & 42,3 \\
\hline Streptococcus spp. & 3 & 11,5 \\
\hline S. aureus + Streptococcus spp & 2 & 7,69 \\
\hline S. aureus + Mycoplasma spp. & 1 & 3,85 \\
\hline Streptococcus spp. + E. coli & 2 & 7,69 \\
\hline S. aureus + E.coli & 2 & 7,69 \\
\hline Streptococcus spp. + S. aureus + E.coli & 2 & 7,69 \\
\hline Enterobacteriacea & 1 & 3,85 \\
\hline Pseudomonas spp. & 2 & 7,69
\end{tabular}

As shown in Table 1, the frequency of bacterial strains isolated from the 26 milk samples of $\mathrm{CMT}^{+}$ dairy cows was dominated by Staphylococcus aureus $(42,31 \%)$ followed by Streptococcus spp. $(11,54 \%)$. However, the other bacterial strains, i.e. Mycoplasma spp., Echerichia coli, Pseudomonas spp., and Enterobacteriacea were found to be very low $(4-8 \%)$.

The CMT test carried on 100 dairy cows from 32 farms showed that about $26 \%$ of cows were $\mathrm{CMT}^{+}$. This result is found to be significantly lower than the SCM prevalence of $43 \%$ recorded in the district of Batticaloa in Srilanka (Sanotharan et al., 2016), and also than the $50.4 \%$ recorded by Mpatswenumugabo et al. (2017). Previously, a very high SCM prevalence was found in East Africa; 86.2\%, 64\% and 59.2\% in Uganda (Abrahmsen et al., 2014), in Kenya (Mureithi and Njuguna, 2016), and in Ethiopia (Abebe et al. 2016), respectively.

A lower prevalence of SCM found in this study can be explained by the fact that the most farmers in the study area practice proper farming management and screen for mastitis at earlier stage (Dry cow therapy, use of teat dips and treatment of clinical cases). Furthermore as mentioned in Mpatswenumugabo et al. (2017) and Sanotharan et al. (2016), several factors affect the prevalence of mastitis within the cow herds, such as; age, parity, stage of lactation, farming system, housing system, calf sucking after milking, milking place (open space; milking from stanchion/tie stalls), milking technique (hand milking and/or milking with machine), hygiene, isolation of infected cows, milk production, and mastitis control (cow hygiene, dry cow therapy, use of teat dips and treatment of clinical cases).

No significant differences $(\mathrm{P}>0.05)$ were recorded in the SCM frequencies between the two livestock systems, i.e. $21.2 \%$ for the semi-intensive and $27.8 \%$ for the intensive farms (Figure 2). This finding is different than the findings showed in previous studies, where the prevalence of mastitis was higher in the intensive system compared to the semi intensive system (Mpatswenumugabo et al., 2017) and the extensive system (Sanotharan et al., 2016). The differences of prevalence rates of subclinical mastitis may be due to the difference of animal breeds, management practices and 
the tests used for screening the milk samples. However, the absence of difference $(\mathrm{P}>0.05)$ in SCM prevalence between the farm systems in our study could be explained by use of the same feed, drugs, and especially same methods of mastitis prevention.

In the present study, the frequency of bacterial strains isolated from the 26 milk samples of $\mathrm{CMT}^{+}$ dairy cows was dominated by the Staphylococcus aureus $(42,31 \%)$ followed by the Streptococcus spp. (11,54\%). However, the other bacterial strains, which include Mycoplasma spp., Echerichia coli, Pseudomonas spp., and Enterobacteriacea, were found to be low (4-8\%).

The findings of this study is closely similar with the findings of Kayesh et al. (2014) who reported the prevalence of Staphylococcus spp. as $73.3 \%$ in both the clinical and subclinical mastitis which was followed by the Streptococcus spp. (33.33\%) and Escherichia coli (6.67\%). Several previous studies reported also that $S$. aureus was the most predominant bacterial isolate in their work, such as Kurjogi and Kaliwal (2014); Deressa et al. (2013) Thorberg (2008); Hogan and Smith (1997).

The environmental bacterial strains belonging to the Streptococci were ranked on second and third position after the Staphylococcus aureus in studies of Hegde et al. (2013) and Mpatswenumugabo et al. (2017), respectively. However, Ostensson et al. 2013 reported the $S$. agalactiae as the most dominant $(21 \%)$ isolated bacteria in their study. As the $S$. aureus is a contagious pathogen therefore its prevalence can be associated with poor milking hygiene and lack of teat dipping (Jones et al., 1998). It has been reported that the $S$. aureus has adaptive mechanisms that allow it to shed on the udder and cause intra-mammary infections during milking process (Radostits et al., 1994).

As reported by Irgaha (2015), in Eastern Rwanda, coliform bacteria were mostly isolated from the SCM positive milk samples. It should, however, be noted that the study of Iraguha et al. (2015) was carried out during the dry season (where there could be the contamination by soil and fecal matter) whereas the current study was conducted during the short rainy season.

\section{Conclusion}

The prevalence of SCM in lactating cows in the studied area (Bejaia district: from Tazmalt to Lakseur), in Algeria was lower reaching 26\%, with no significant influence of a farming system type, and a predominance of Staphylococcus aureus as a major bacterial causal agent.

Acknowledgments. Authors are grateful to all farmers contributing to the realization of this work

\section{References}

1. Abdeldjalil MC (2005). Suivi sanitaire et zootechnique au niveau d'élevages de vaches laitières mémoires de Magistere. Université Mentouri de Constantine. https:// bu.umc.edu.dz/theses/veterinaire/ABD4261.pdf

2. Abebe R, Hatiya H, Abera M, Megersa B, Asmare K (2016). Bovine mastitis: prevalence, risk factors and isolation of Staphylococcus aureus in dairy herds at Hawassa milk shed, South Ethiopia. BMC Veterinary Research, 12: 27011.

3. Abrahmsen M, Persson Y, Kanyima B M, Age RB (2014). Prevalence of subclinical mastitis in dairy farms in urban and peri-urban areas of Kampala, Uganda. Tropical Animal Health and Production, 46:99-105.

4. Biru G (1989). Major bacteria causing bovine mastitis and their sensitivity to common antibiotics. Ethiopia. Journal of Agricultural Science, 11:4 7 - 54

5. Bouzid R, Hocine A, Maifia F, Rezig F, Ouzrout R, Touati K (2011) Prévalence des mammites en élevage bovin laitier dans le Nord-Est algérien. Livestock Research for Rural Development. Volume 23. http://www.lrrd.org/ lrrd23/4/bouz23073.htm

6. Deressa B, Begna F, Mekuria A (2013). Study on prevalence of bovine mastitis in lactating cows and associated risk factors in and around Areka town, Southern of Ethiopia. African Journal of Microbiology Research, 43: 5051-5056

7. Guerin-Faublee V, Carret G, Houffschmitt P (2003) In vitro activity of 10 antimicrobial agents against bacteria isolated from cows with clinical mastitis. Veterinary research, 152: 466-471

8. Hegde R, Isloor S, Prabhu KN, Shome BR, Rathnamma D, Suryanarayana VVS, Yatiraj S, Prasad CR, Krishnaveni N, Sundareshan S, Akhila DS, Gomes AR, Hegde NR (2013). Incidence of subclinical mastitis and prevalence of major mastitis pathogens in organized farms and unorganized sectors. Indian Journal of Microbiology, 53: 315320

9. Hogan JS, Smith KL (1997). Bacteria count in sawdust bedding. Journal of Dairy Science, 80: 1600-1605

10. Iraguha B, Hamudikuwanda H, Mushonga B (2015). Bovine mastitis prevalence and associated risk factors in dairy cows in Nyagatare District, Rwanda Journal of the South African Veterinary Association 86: 1-6

11. Jones GM, Bailey TL, Roberson GR (1998). Staphylococcus aureus Mastitis: Cause, Detection, and Control, Virginia State University, http://www.thecattlesite.com/ articles/679/staphylococcus-aureus-mastitis-causedetection-and-control/ 
12. Kali S, Benidir M, Ait Kaci K, Belkheir B, Benyoucef MT (2011). Situation de la filière lait en Algérie: Approche analytique d'amont en aval. Livestock Research for Rural Development. http://www.lrrd.org/lrrd23/8/Kali23179. htm;

13. Kurjogi MM, Kaliwal BB (2014). Epidemiology of bovine mastitis in cows of Dharwad district. International Scholarly Research Notices. Article ID 968076, 9 pages, http://dx.doi.org/10.1155/2014/968076

14. Kayesh MEH, Talukder M, Anower AKM (2014). Prevalence of subclinical mastitis and its association with bacteria and risk factors in lactating cows of Barisal district in Bangladesh. International Journal of Biological Research, 2: 35-38

15. Mpatswenumugabo JP, Bebora LC, Gitao GC, Mobegi VA, Iraguha B, Kamana O, Shumbusho B (2017). Prevalence of Subclinical Mastitis and Distribution of Pathogens in Dairy Farms of Rubavu and Nyabihu Districts, Rwanda. Journal of Veterinary Medicine. Article ID 8456713. https://www. hindawi.com/journals/jvm/2017/8456713/

16. Mureithi DK, Njuguna MN (2016). Prevalence of subclinical mastitis and associated risk factors in dairy farms in urban and peri-urban areas of Thika Sub County, Kenya. Livestock Research for Rural Development. Vol, 28 from http://www.lrrd.org/lrrd28/2/mure28013.html

17. Pfützner M, Ózsvári L (2017). The Financial Impact of Decreased Milk Production Due to Subclinical Mastitis in German Dairy Herds. Journal of faculty of veterinary medicine of Istanbul University, 43:110-115

18. Poutrel B (1985). Généralités sur les mammites des vaches: processus infectieux épidémiologie diagnostique et méthodes de contrôle. Research medecine veterinary, 161:497-51

19. Radostits OM, Leslie KE, Fetrow J (1994) Herd Health: Food Animal Production Medicine. W.B Saunders Philadelphia Pa USA, $2^{\text {nd }}$ edition. cocci, pp. 36-41.

20. Radostis OM, Gay CC, Hinchcliff KW, Constable D (2007). Veterinary Medicine: A Textbook of the diseases of Cattle Horses Sheep Pigs and Goats. 10th Edn Grafos S A Arte Sobre Papel Spain pp: 823-835.
21. Saidi R, Khelef D, Kaidi R (2016). Incidence et étiologie Subclinical mastitis in dairy cattle herds in the central region of Algeria: incidence and etiology. Rencontres de la Recherche sur les Ruminants. http://www.journees3r.fr/ IMG/pdf/Texte_13_sante_R-Saidi.pdf

22. Sanotharan N, Pagthinathan M, Nafees MSM (2016). Prevalence of Bovine Subclinical Mastitis and its Association with Bacteria and Risk Factors in Milking Cows of Batticaloa District in Sri Lanka. International Journal of Scientific Research and Innovative Technology, 3: 2313-3759.

23. Seegers H, Fourichon C, Beaudeau F (2003). Production effects related to mastitis and mastitis economics in dairy cattle herds Veterinary Research 34: 475-491

24. Semmar A (2018) Décryptage. Pourquoi l'Algérie ne produit pas le lait qu'elle boit. Algérie Part : Les dessous de l'actualité. https://algeriepart.com/2018/03/06/ decryptage-lalgerie-ne-produit-lait-boit/

25. Serieys F (1985) Cell counts in milk from individual cows, infl uence of mammary infection parity, stage of lactation and milk yield. Annales De Recherches Veterinaire, 16: 255-261

26. Shahid M, Sabir N, Ahmed I, Khan RW, Irshad M, Rizwan M, Ahmed S (2011). Diagnosis of subclinical mastitis in bovine using conventional methods and electronic detector. ARPN Journal of Agricultural and Biological Science 6: 18-22.

27. Singh PJ, Sing KR (1994). A study of economic losses due to mastitis in India. Indian Journal of Dairy Science 47: 265-272

28. Thorberg BM (2008). Coagulase-Negative Staphylococci in Bovine Sub-Clinical Mastitis, Sveriges lantbruksuniv, Uppsala, Sweden

29. Waage S, Jonsson P, Franklin A (1994). Evaluation of cowside test for detection of gram negative bacteria in milk from cows with mastitis. Acta Veterinaria Scandinavica 35: $207-212$ 